BNL -47666

\title{
AN UPDATE ON ENVIRONMENTAL, HEALTH AND SAFETY ISSUES OF INTEREST TO THE PHOTOVOLTAIC INDUSTRY
}

\author{
P.D. Moskowitz, J. Viren and V.M. Fthenakis \\ Analytical Sciences Division \\ Department of Applied Science \\ Brookhaven National Laboratory \\ Upton, New York 11973
}

BNL- -47666

DE92 016951

\begin{abstract}
There is growing interest in the environmental, health, and safety issues related to new photovoltaic technologies as they approach commercialization. Such issues include potential toxicity of II-VI compounds; the impacts of new environmental regulations on module manufacturers; and, the need for recycling of spent modules and manufacturing wastes. This paper will review these topics.

\section{INTRODUCTION}

Environmental, health and safety aspects of photovoltaic energy systems and related semiconductor processes have been discussed at several conferences $1-3$ and in the open literature 4-6. Technical issues explored in these papers range from hazards to occupational health associated with the handling of toxic substances, to risks to public health from electrical shock hazards. An important issues which is discussed in many of these papers is the need to adequately understand and manage hazards presented by toxic or hazardous materials, especially in the module manufacturing environments. The state-of-knowledge with respect to hazards presented by chemicals used in photovoltaic module manufacture is constantly advancing. Federal statutes and regulations impacting on material usage and disposal are attempting to keep pace with this new knowledge. This paper updates the existing literature on this topic by summarizing recently developed information on the toxicology of Cd compounds; the potential impact of new Clean Air Act Amendments on photovoltaic module marlufacturers; and the results of a recent workshop to analyze options for the recycling of $\mathrm{Cd}$ and $\mathrm{Se}$ from photovoltaic modules and production wastes.
\end{abstract}

\section{UPDATE ON THE TOXICITY OF Cd COMPOUNDS}

This section gives an update on the potential toxicity of $\mathrm{Cd}$ compounds. Using data on CdS we speculate on the relative potency of CdTe and some of the uncertainties regarding the proposed revision in the Occupational Safety and Health Administration (OSHA) Permissible Exposure Limit (PEL) for airborne Cd exposure. At issue, is the sufficiency of evidence classifying all $\mathrm{Cd}$ compounds as equally potent lung carcinogens 7 . 


\section{Carcinogenicity and Physicochemical Properties}

Qualitative evidence of $\mathrm{Cd}$ carcinogenicity in rats and mice indicates that most $\mathrm{Cd}$ compounds can induce tumors 8,9 . Subcutaneous and intraperitoneal injection of $\mathrm{Cd}$ metal in powder form, soluble salts and the highly insoluble $\mathrm{CdS}$, all induce injection site sarcomas, abdominal cavity tumors, and distant site tumors of the pancreas and prostate. These tests, however, cannot be used to establish dose-response, tumor specificity, or carcinogenic potential through other routes of administration. For example, oral administration of $\mathrm{Cd}$ salts in the same species has not indicated an increased carcinogenic risk resulting from ingestion.

Results of a recent intraperitoneal injection study of $\mathrm{Ni}$ and $\mathrm{Cd}$ compounds in young female Wistar rats 10 are shown in Table $1 . \mathrm{CdO}$ and $\mathrm{CdS}$ were administered at concentrations near the maximally tolerated dose. The differential in dose is indicative of the high acute toxicity of "soluble" and "medium soluble" $\mathrm{Cd}$ compounds relative to $\mathrm{CdS}$. Evidence of tumor induction was seen only for $\mathrm{CdS}$ with a tumor rate of about 66 percent while the tumorogenicity of $\mathrm{CdO}$ was comparable to the saline control.

Pott ${ }^{10}$ also investigated lung tumor induction via short-term intratrachial exposure to $\mathrm{CdCl}_{2}, \mathrm{CdO}$, and $\mathrm{CdS}$ in young female Wistar rats. The range in dose rate and cumulative exposure was determiner by the acute lung toxicity, which was clearly related to the solubility of the compound. As expected, animals exposed to the highly insoluble $\mathrm{CdS}$ tolerated a very high dose rate, compared to $\mathrm{CdCl}_{2}$ exposure (Table 1). Animals dosed at 10,000 ug of $\mathrm{CdS}$, demonstrated a significantly higher mortality rate, reflecting CdS toxicity. All lung tumors in the rat have a very late onset, so the lifeshortening is also reflected in the tumor rate. Pott concluded from these data that the general bioavailability of $\mathrm{CdO}$ was a factor of ten greater than $\mathrm{CdS}$. Others ${ }^{9}$ indicate that $\mathrm{CdCl}_{2}$ probably has a bioavailability twice that of $\mathrm{CdO}$ in the rat. In the series shown in Table 1, cumulative lung tumor incidence in animals exposed to $630 \mathrm{ug}$ of $\mathrm{CdS}$ was similar to the incidence observed at $60 \mathrm{ug} / \mathrm{m}^{3}$ of $\mathrm{Cd} 0$ showing that the relative potency of $\mathrm{CdO}$ was about a factor of ten greater than $\mathrm{CdS}$. These data suggest a clear difference in carcinogenic potency associated with apparent bioavailability. Other evidence indicated that the type of tumor might be effected by the dose rate/bioavailability.

The recently complcted long-term inhalation study in the rat by Oldiges et al. 11 confirms the notion that most $\mathrm{Cd}$ compounds are lung carcinogens at some dose. Carcinogenicity was evident in both sexes, and for all compounds under study (i.e., $\mathrm{CdCl}_{2}, \mathrm{CdSO}_{4}, \mathrm{CdO}$, and $\mathrm{CdS}$ ). However, this was an ambitious study that was severely constrained by the unexpected toxicity associated with all compounds tested. In an earlier investigation by Takenaka et al. 12 , rats had been exposed continuously for 18 months to $\mathrm{CdCl}_{2}$ at nominal levels of $12.5,25$, and $50 \mathrm{ug} / \mathrm{m}^{3}$ without evidence of severe toxicity. In this study, with the exception of CdS, animals were exposed at 30 and $90 \mathrm{ug} / \mathrm{m}^{3}$, for 18 months of continuous exposure. For CdS, exposures were at 90 , 270,810 , and $2,430 \mathrm{ug} / \mathrm{m}^{3}$, the higher doses reflecting the lower "perceived" toxicity associated with this compound. Except for $\mathrm{CdS}$, all compounds demonstrated delayed toxicity at $90 \mathrm{ug} / \mathrm{m}^{3}$, showing increased mortality from pulmonary disease. Delayed toxicity was observed for CdS, but at the nominal level of $270 \mathrm{ug} / \mathrm{m}^{3}$ where 
Table 1. Tumor Induction resulung Irom Short-term Exposure to selected Cadmium Compcunds: Resuts from Intraperotineal injection and Intratracheal Instillation. (1.3)

\begin{tabular}{ccccc}
\hline Exposure Scenario & $\begin{array}{c}\text { Dose Rate } \\
\text { (wooks } \times \text { dose) }\end{array}$ & $\begin{array}{c}\text { Cumulative } \\
\text { Dose }\end{array}$ & No. of Animals & $\begin{array}{c}\text { Percent with } \\
\text { Tumore }\end{array}$ \\
\hline
\end{tabular}

Intraperotineal Injoction

\begin{tabular}{|c|c|c|c|c|}
\hline Saline Control & $1 \mathrm{ml}$ at 0 & percent & 32 & 6.3 \\
\hline Cadmium Oxide & $2 \times 0.125 \mathrm{mg}$ & $0.25 \mathrm{mg}$ & 47 & 6.4 \\
\hline Cadmium Sulfide & $1 \times 50 \mathrm{mg}$ & $50 \mathrm{mg}$ & 81 & 66.7 \\
\hline & Intrat & heal Instillat & & \\
\hline Controls (Saline) & - & - & 40 & 0 \\
\hline Cadmium Chloride & $20 \times 1$ ug & $20 \mathrm{ug}$ & 38 & 0 \\
\hline Cadmium Chloride & $20 \times 3$ ug & 60 ug & 40 & 7.5 \\
\hline Cadmium Oxide & $20 \times 1$ ug & 20 ug & 37 & 5.4 \\
\hline Cadmium Oxide & $20 \times 3$ ug & 60 us & 40 & 5.1 \\
\hline Cadmium Sulfide & $10 \times 63$ us & 630 ug & 39 & 5.1 \\
\hline Cadmium Sulfide & $10 \times 250$ ug & 2,500 ug & 36 & 22 \\
\hline Cadmium Sulfide & $10 \times 1,000$ ug & 10,000 ug & 36 & 19 \\
\hline
\end{tabular}

1. Pou F, Zeim U., Reiffer F J, and otherz. "Carcinogenicity sudies on fibers, metal compounds, and rome oth. a dusts in rute" Exo Pathol 32.(1987): 129-152.

2. All experimental series besed on frnale Wistar rats, spproximately $3 \mathrm{mo}$. of age at initial exposure. Animals were adninistered the given dose once weck until the specified cumbulsteve exposure was atthinod Animals were then obeerved through the remuining lifo-epen - about $2.3 \mathrm{yr}$.

3. Endpoints for i.p. injoction were sarcomens, other tumors of the abdominal cavity. Intratructeal insullistion yiekded verious hung tumon including berigen adenomea. 
animals were exposed for only 16 months. Table 2 summarizes the compound-spesific tumor incidence by dose and exposure duration.

The argument that $\mathrm{CdS}$ has a relative potency equal to other $\mathrm{Cd}$ compounds is consistent only with comparisons made at the $90 \mathrm{ug} / \mathrm{m}^{3}$ dose. Comparisons based on $\mathrm{CdS}$ exposure at $270 \mathrm{ug} / \mathrm{m}^{3}$, might indicate a relative potency lower by a factor of three than that of CdO. There was, however, evidence of toxicity in that group of animals, so such an estimate is uncertain. In effect, the data demonstrated carcinogenicity for all compounds, but make no significant contribution to the question of bioavailability.

Oberdorster and $\operatorname{Cox}^{9}$ compared the sex-specific tumor incidence observed in this study, with the corresponding maximum likelihood estimates computed from the Takenaka $\mathrm{CdCl}_{2}$ exposure data. They concluded that data from the present study was consistent with the dose-response observed with $\mathrm{CdCl}_{2}$. This doesn't infer that there is equivalent potency across compounds including $\mathrm{CdCl}_{2}$. The general uncertainty in this study is exemplified by the results reported for $\mathrm{CdCl}_{2}$ exposure. In the Takenaka et al. 12 study, a tumor rate of 71 percent was observed at a dose of $50 \mathrm{ug} / \mathrm{m}^{3}$. This is compared to 74 percent, at a nominal exposure of $30 \mathrm{ug} / \mathrm{m}^{3}$ in this investigation.

When the exposures were prematurely terminated, the tumor incidence would be influenced by the shortened life span, and differences in the particle clearance and retention time. Although higher dose rates for shorter periods, may yield the same cumulative dose, changes in retention and clearance would markedly effect tissue Cd concentration after cessation of exposure. Thus, these data are not very useful in addressing either the relative carcinogenic potency, or the bioavailability question. It seems unfortunate that a significant amount of the data collected in the Glaser/Oldiges study has limited value for quantitative purposes.

To determine if particle size and the higher specific surface area of $\mathrm{CdO}$ fume might alter CdO carcinogenicity, male Wistar rats were exposed to CdO fume (mass median diameter $<0.1 \mathrm{um}$ ) at 30 and $10 \mathrm{ug}$. Exposure to $\mathrm{CdO}$ dust was at levels of 30 and $90 \mathrm{ug} / \mathrm{m}^{3}$, in both sexes, with and without simultaneous exposure to zinc oxide. All exposures were continuous for eighteen months. These experimental results are showr in Table 3. Comparisons of tumor incidence for fume and dust at $30 \mathrm{ug} / \mathrm{m}^{3}$ indicated that dust exposure was about three times more potent. Further, over 60 percent of the tumors in the fume-exposed animals were benign, in contrast to less then 20 percent in dust exposed rats. No data on CdO fume deposition were collected, but it is likely that the differences in tumor incidence reflect differential lung deposition. At the end of the study ( 31 months), the lung $\mathrm{Cd}$ concentration in fume-exposed rats was a factor of six lower then in the dust exposed, affirming the supposition of lower lung deposition. Fume exposure to $10 \mathrm{ug} / \mathrm{m}^{3} \mathrm{did}$ not induce tumors.

Other inhalation studies in rats at high, but sub-chronic exposure, have shown a strong correlation between the severity in lung histopathology and the induction of $\mathrm{Cd}$ binding proteins in the lung 13 . In Hart's study, animals were exposed to a $\mathrm{CdO}$ aerosol containing $1,600 \mathrm{ug} / \mathrm{m}^{3}$ of Cd for one to six weeks ( $3 \mathrm{hr} /$ day, 5 days $/$ week). Severe inflammation and other lung pathology were noted in the first two weeks of exposure, but returned to normal during the next four weeks, although exposure continued. After a short induction period, lung metallothionien increased rapidly 
Table 2 Comparison of Lung Cancer in Wistar Rats by Duration and Level of Exposuro to Cadmum Sulfide and other Cadmlum Compounds - Both Sexes Combined $(1,2)$

\begin{tabular}{|c|c|c|c|c|}
\hline Cd Expocuro Scenarto & $\begin{array}{l}\text { Exposure } \\
\text { in Mortine }\end{array}$ & No. of Animale & $\begin{array}{c}\text { Toted Tumons in Pur. } \\
\text { cant }\end{array}$ & $\begin{array}{c}\text { Bron hiloalveolar Adeno. } \\
\text { inas in Pet A }\end{array}$ \\
\hline \multicolumn{5}{|c|}{ 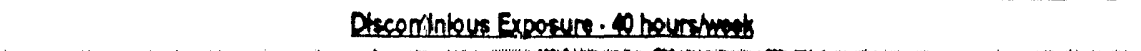 } \\
\hline \multirow{2}{*}{\multicolumn{5}{|c|}{ 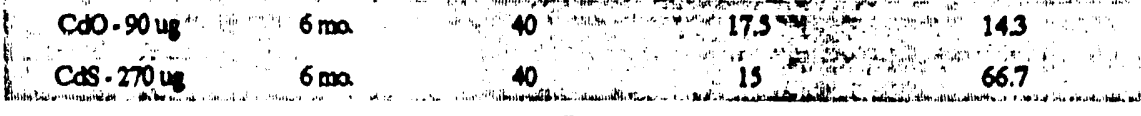 }} \\
\hline & & & & \\
\hline \multicolumn{5}{|c|}{ Coninious Exposime } \\
\hline $\mathrm{CdCl}_{2} \cdot 30$ us & 18 & 38 & 74 & 21.3 \\
\hline $\operatorname{cdo} .30$ ug $_{8}$ & 18 & 40 & 75 & 23.3 \\
\hline CAsO, 90 ug & 18 & 40 & 72.5 & 20.6 \\
\hline $\operatorname{Cos} \cdot 90$ ug & 18 & 40 & 80 & 12.5 \\
\hline CAs. 270 us & 16 & 38 & 79 & 6.7 \\
\hline \multicolumn{5}{|c|}{ Continhous Exposune Evidence of Iosctir } \\
\hline $\cos \cdot 810$ ug & $7.10 \mathrm{ma}$ & 40 & 60.1 & 20.8 \\
\hline $\cos \cdot 2,430$ ug & $3-4 \mathrm{mo}$. & 39 & 37.1 & 30.8 \\
\hline $\mathrm{CdCh}_{4} \cdot 90$ ug & $6 \mathrm{ma}$ & 38 & 34.2 & 23.1 \\
\hline $\mathrm{CdO} .90$ ug & $7.11 \mathrm{mo}$ & 33 & 60.6 & 20 \\
\hline \multicolumn{5}{|c|}{ 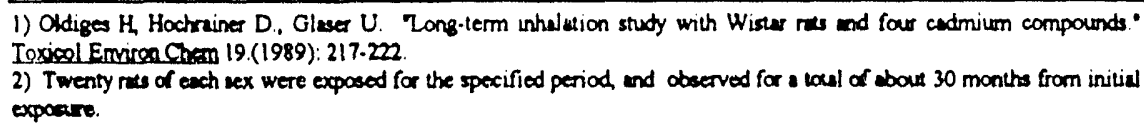 } \\
\hline \multicolumn{5}{|c|}{ 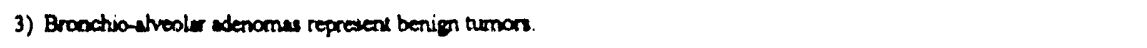 } \\
\hline
\end{tabular}

Table 3. Lung Cancers in Wistar Rats resulting from 18 Months of Exposure to Cadmium Oxdde Dust and Fume $(1,2)$

\begin{tabular}{|c|c|c|c|}
\hline Cd Exposine Scanorto & No. of Animats & $\begin{array}{c}\text { Total Tumors in Per. } \\
\text { cant }\end{array}$ & 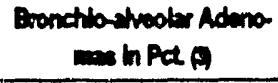 \\
\hline Cantule & 40 & $a$ & $a$ \\
\hline \multicolumn{4}{|c|}{ 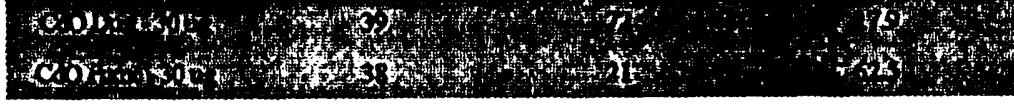 } \\
\hline Cdo Pume - 10 us & 40 & $a$ & $a$ \\
\hline $\begin{array}{l}\text { CdODan- } 30 \text { ug + } \\
200 \cdot 300 \text { ug }\end{array}$ & $\omega$ & $a$ & $a$ \\
\hline $\begin{array}{l}\text { CdODux- } 90 \text { ug + } \\
250.900 \text { ug }\end{array}$ & 40 & 37.5 & 13.3 \\
\hline 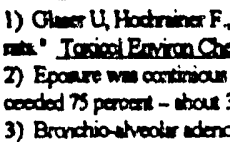 & 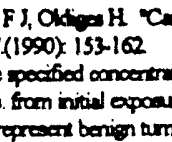 & 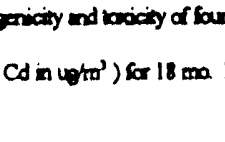 & \\
\hline
\end{tabular}


throughout the exposure period and changes in the pattern of lung pathology were associated with this increase. The effects of $\mathrm{Zn}$ exposure seen in the Glaser study are consistent with the enhanced induction of lung metallothionein by zinc, resulting in reduced toxicity and carcinogenicity. Whether such data suggest a practical threshold for $\mathrm{Cd}$ carcinogenicity at very low dose remains to be explored.

\section{Estimation of CdTe Health Effects}

To characterize the risks to health presented by $\mathrm{CdTe}$, data for other $\mathrm{Cd}$ compounds must be used. A logical starting point for such an extrapolation is the data for CdS. Sulfur and tellurium share adjacent positions in the periodic table, and have similar physical properties. Both are extremely insoluble in water; slightly soluble with decomposition in dilute nitric acid; have very high boiling point with sublimation; and slow decomposition in moist air. Biologic properties of CdS like the solubility rate, particle clearance/retention, and effective bioavailability are probably equally valid for CdTe.

Until 1986 there were few data, detailing the chronic toxicology or carcinogenicity of CdS. Because of its low solubility, risks were considered less than for soluble compounds, but by "how much" was not known. The apparently low bioavailability has been cited as one factor, that might explain the relatively low carcinogenicity of mixed $\mathrm{Cd}$ exposure in occupational studies 14 . The Glaser et al. 15 chronic inhalation study of $\mathrm{Cd}$ compounds in the rat, briefly summarized here, represented the most comprehensive investigation of $\mathrm{CdS}$ to date. The range of $\mathrm{Cd}$ exposures in that investigation, clearly reflected the view that CdS was significantly less carcinogenic than other $\mathrm{Cd}$ compounds, and high doses could be well tolerated, since acute and sub-chronic toxicity were minimal in earlier lung instillation studies.

Oldiges and Glaser 16, however, have indicated severe chronic toxicity associated with almost all $\mathrm{CdS}$ exposures. This was associated with increased lung weights and enlarged thoracic lymph nodes at necropsy that was independent of carcinogenicity and was reflected in a median life expectancy 2-6 months less than the controls. Extended necropsy data have not been published yet, so specific contrast with other $\mathrm{Cd}$ compounds is not possible.

\section{Regulatory Perspective}

OSHA $^{17}$ and others have concluded that all $\mathrm{Cd}$ compounds tested in the rat bioassay have equal carcinogenic potency, regardless of physicochemical characteristics. Given the stated equality in lung cancer potency, OSHA risk estimates from the Takenaka data suggest an 8-hour PEL in the range of $0.48 \mathrm{ug} / \mathrm{m}^{3}$ from the animal model 18. The comparable PEL based on human epidemiological evidence is $3.11 \mathrm{ug} / \mathrm{m}^{3}$. Although the estimated PELs from animal and human data differ by about a factor of six, both are consistent with the recently proposed standard of 5 $\mathrm{ug} / \mathrm{m}^{3}$. In contrast to the present standard, the proposed PEL makes no provision for particle size (fume and dust), nor differences in solubility and other factors, that mediate the bioavailability of specific Cd compounds. 
Although carcinogenicity is a critical health end-point for regulatory purposes, OSHA has considered adequate protection against irreversible and progressive renal disease to be equally compelling. The proposed revision takes into account "kidney dysfunction", defined as an increase in urinary b-2 microglobulins, retinol binding protein, and/or increased total urinary protein. The actual association between these "biomarkers" and the prevalence of irreversible and progressive renal disease is relatively weak and nonspecific at low exposure. Agency risk analyses 18 show that a PEL of $5 \mathrm{ug} / \mathrm{m}^{3}$ is consistent with the human evidence denonstrating an increased prevalence of urinary proteinuria among workers with cumulative exposure exceeding $500 \mathrm{ug} / \mathrm{m}^{3}$-years. Evidence is wholly based on human data; bioavailability isn't at issue since metabolism and detoxification of all $\mathrm{Cd}$ species ultimately involves the kidney. In the regulatory context equality in carcinogenic potency is convenient since it unifies the two health end-points, but isn't necessary to justify the level in the proposed PEL.

\section{CLEAN AIR AC I AMENDMENTS OF 1990}

In November of 1990 , the President signed into law the 1990 Clean Air Act Amendments. These Amendments contain some of the most detailed guidance ever included within environmental packages passed by the Congress. The Act contains various Titles. One that has aroused great interest to operators/owners of facilities that generate hazardous air emissions or handle extremely hazardous chemicals is Title IIIAir Toxics. Two key provisions of this Title (Section 301 and Section 304) and their potential impact on the photovoltaics industry are outlined below.

\section{Section 301 - Hazardous Air Pollutant Requirements}

In 1990, major revisions were made to the statutory and regulatory approaches for controlling toxic air pollution emissions from point sources. These changes were incorporated into the newly authorized Clean Air Act. In this Act, an aggressive strategy for controlling hazardous air pollutant emission standards for routine releases from stationary sources was adopted. More specifically, Title III lists 189 hazardous air pollutants (including As, $\mathrm{Cd}$ and Se compounds) and directs EPA to promulgate maximum achievable control technology (MACT) standards for industrial sources emitting these contaminants in quantities exceeding 10 tons per year. MACT standards may be achieved through process changes, installation of pollution controls, materials substitution, or operator training and certification. Should these controls fail to provide an ample margin of safety to public health, e.g., a residual cancer risk exceeding one in 10,000 to the most exposed person, the EPA Administrator is required to develop more stringent emission limits. In developing MACT standards, the EPA Administrator may apply different emission standards to new and existing sources. The criteria used in deciding such standards would be based on special considerations of the cost and feasibility of control, energy impacts, and environmental factors. However, any new source must achieve the maximum degree of reduction in emissions that is deemed achievable for the best controlled existing similar source. Thus, standards for new 
sources are likely to be more stringent than those for existing sources. Although, it is highly unlikely that a photovoltaic manufacturing facility could emit emissions in these quantities, this program is still important because of the regulatory focus placed on several materials used in photovoltaic cell manufacture (Table 4).

Table 4. Selected Hazardous Air Pollutants to Be Regulated under the Clean Air Act Title III Requirements

\begin{tabular}{|l|l|}
\hline Antimony Compounds & Arsenic Compounds \\
\hline Beryllium Compounds & Cadmium Compounds \\
\hline Chromium Compounds & Cobalt Compounds \\
\hline Glycol Ether & Lead Compounds \\
\hline Mercury Compounds & Nickel Compounds \\
\hline Selenium Compounds & \\
\hline
\end{tabular}

\section{Section 304 - Process Safety Standards}

In contrast with past environmental legislation which focused principally on the roles and responsibilities of the EPA, Section 304 defines a joint role for both EPA and OSHA in chemical accident prevention. More specifically, Section 304 directs the Secretary of Labor to promulgate under authorities of the Occupational Safety and Health Act of 1970, chemical process safety standards to protect employees from hazards associated with accidental releases of extremely hazardous substances. The first set of regulations responding to this Section were promulgated by OSHA in February of 199219 . These regulations focus on the development of a comprehensive management program, according to which individual companies can develop a safety strategy tailored to their spexific processes. This strategy should be based on integrating technologies, procedures and management practices. The standard details the elements and performance measures so that each facility can develop the most appropriate management system to meet its particular needs. Representative items to be included in the development of such safety plans, include but are not limited to:

- Employee Involvement in Process Safety Management - The Act states that employers are to consult with their employees and representatives regarding the employers efforts to develop and implement a process safety and hazard assessment program.

- Compilation of Process Safety Information - Complete and accurate written information concerning process chemicals, process technology and process equipment is essential to an effective process safety management program.

- Process Hazard Analysis - A process hazard analysis (PHA) is one of the most important element of the process safety management program. A PHA is an organized and systematic effort to identify and analyze the significance 
of potential hazards associated with the processing or handling of highly hazardous chemicals.

- Operating Procedures and Practices - Operating procedures describe tasks to be performed, data to be recorded, operating conditions to be maintained, sample to be collected and safety and health precautions to be taken.

- Employee Training - All employees including maintenance and contractor employees involved with highly hazards chemicals need to fully understand the safety and health hazards of the chemicals and process they work with *for protection of themselves, their fellow employees and the citizens of nearby communities.

- Contractors - Employees who use contractors to perform work in and around processes that involve highly hazards chemical, will need to establish a screening process so that they hire and use contractors who can accomplish the desired jobs without compromising the safety and health of employees at the facility.

- Pre-Startup Safety - The initial start-up procedures and normal operating procedures need to be fully evaluated as part of the prestartup review of any new or modified equipment to assure a safe transfer into the normal operating mode for meeting the process design parameters.

- Mechanical Integrity - Employers will need to review their maintenance programs and schedules to see if there are areas where "breakdown" maintenance is used rather than an on-going mechanical integrity program. Equipment used to process, store or handle highly hazardous chemicals needs to be designed, constructed, installed and maintained to minimize the risk of releases of such chemicals.

- Nonroutine Work Authorizations - Nonroutine work which is conducted in process areas need be controlled by the employer in a consistent manner. A work authorization notice must have a procedure that describes the steps the maintenance supervisor, contractor, or other person needs to tuit w to obtain the necessary clearance to get the job started.

- Managing Change - Changes in equipment, operating procedures, raw materials, etc. must be actively managed.

- Investigation of Incidents - Incident investigation is the process of identifying the underlying causes of incidents and implementing steps to prevent similar event from recurring. The intent of an incident investigation is for employers to learn from past experiences and thus avoid repeating past mistakes. 
- Emergency Preparedness - Each employer must address what actions employees are to take when there is an unwanted release of highly hazardous chemicals.

- Compliance Audits - Employers need to select a trained individual or assemble a trained team of people to audit the process safety management system and program. The audit should include an evaluation of the design and effectiveness of the process safety management system, and a field inspection of the safety and health conditions and practices to verify that the employer's systems are effectively implement.

The standard identifies more than 130 toxic and reactive chemicals and threshold quantities which trigger compliance with this Act. A partial listing of these chemicals and their threshold quantities is given in Table 5. These quantities are likely to exceed those present in large-scale photovoltaic module manufacturing facilities. Thus, module manufacturers will probably not be directly covered by this statute. Nevertheless, it is clear, that the spirit, intent and procedures outlined in these regulations should not be ignored.

Table 5. Partial Listing of Toxic and Reactive Highly Hazardous Chemicals Which Present a Potential for A Catastrophic Event at or Above the Threshold Quantity

\begin{tabular}{|l|l|l|}
\hline Chemical Name & CAS & Threshold Quantity (lbs) \\
\hline Arsine & $7784-42-1$ & 100 \\
\hline Dichlorosilane & $4109-96-0$ & 2500 \\
\hline Hydrofluoric Acid, Anhydrous & $7664-39-3$ & 1000 \\
\hline Hydrogen Fluoride & $7664-39-3$ & 1000 \\
\hline Hydrogen Selenide & $7783-07-5$ & 150 \\
\hline Hydrogen Sulfide & $7783-06-4$ & 1500 \\
\hline Phosphorus Oxychloride & $10025-87-3$ & 1000 \\
\hline
\end{tabular}

\section{RECYCLING STRATEGIES}

As the commercial potential of polycrystalline thin-film technologies becomes more apparent, interest in the environmental, health and safety issues associated with their production and use has also increased for three reasons. First, many governmental organizations, industry groups and private citizens have been placing greater emphasis on the need to ensure that new energy producing technologies will have a positive effect on health and the environment. Second, $\mathrm{Cd}$ and Se are metals which continue to receive large regulatory [e.g., The Resource Conservation and Recovery Act (RCRA)] scrutiny because of their toxicological properties. Third, programs are already being established to reduce and/or recycle these materials in other industries. These combine to focus interest on the environmental barriers to the commercial production of CdTe and CIS photovoltaic modules. Because of the large 
interest in this topic, a Workshop was recently held to explore technical and institutional options for the recycling of $\mathrm{Cd}$ and Se from spent CdTe and CIS modules and related production wastes. At this Workshop, representatives from the photovoltaic, electric utility, and nonferrous metals industries met to identify and discuss potential recycling options. A report in preparation summarizes the results of the Workshop 20 .

At this workshop, participants concluded, that the different photovoltaic market segments will differ in their recycling infrastructure requirements, as well as in the urgency with which they must be addressed. Based upon immediate need, the manufacturing, and utility (remote and grid connected) power markets would need to be initially addressed, while the development of recycling options for the consumer market can be delayed for several years. Large-scale disposal of spent photovoltaic devices will not occur until 20 to 30 years after their initial installation. The principal short-term concern will focus on the disposal or re-processing of production wastes. At the present time, it is an open question, whether or not thin film CdTe and CIS modules will be classified as a hazardous materials. In the U.S., the EPA defines hazardous materials as those that fail the Toxicity Characterization Leachate Profile (TCLP) test. Very few thin film modules have been tested by the TCLP procedure. As a result it is not now possible to say whether CdTe or CIS modules or related production wastes will be classified as hazardous. Furthermore, it may be possible to design future thin film modules so that they will pass the TCLP test. Recycling, however, may still be desirable for political and social reasons.

At the Workshop, many options for the recycling of spent modules and production wastes were identified. These can be divided into two broad classes: Centralized and Decentralized. Implementation of the centralized technologies implies that wastes will be shipped from manufacturing locations and consumer locations (e.g., an electric utility) to large facilities engaged in the collection and recycling of wastes. Decentralized options are more focused on the management of wastes at module production facilities. Thus, the decentralized options are smaller in scale and more focused on production wastes.

In general, the centralized options revolve around technologies being used for the recovery of these same materials from raw ores (e.g., nonferrous metal smeiters) or from consumer products (e.g., Cd recovery from $\mathrm{Cd} / \mathrm{Ni}$ batteries via pyrometallugrical methods). Large capacity, far in excess of any photovoltaic need for the next 20 years, is available in these types of operations. The key issues associated with their application to the photovoltaic market are maintenance of institutional control and cost.

One impediment to recyciing may relate to industry's ability to maintain institutional control over photovoltaic modules supplied to the marketplace. This will depend on the nature of the products and consumers. Photovoltaic products may range from small scale battery recharges (several watts), to moderate scale residential or commercial arrays $\left(1-100 \mathrm{~kW}_{\mathrm{p}}\right)$, to large-scale central-station utility applications (MWP). Consumers may include individuals, small businesses and large corporations (e.g., regulated utilities). The ability to maintain institutional controls closely follows these groupings. That is, maintaining institutional control over small products sold to individual consumers will be very difficult. The best method for these groups may be 
to provide incentives (e.g., rebates on new products, deposits, and rewards) for the return of retired devices. For this to occur, the products must include clear identification of who the product should be returned to and what will be provided in return (e.g., money). Utilities retiring large quantities of modules are clearly identifiable and responsible organizations. There must be benefits to these organizations as well. This could include, return of deposits, and perhaps more importantly compliance with RCRA, if the modules are classified as hazardous. The middle-sized group may present the largest problem with respect to recycling because of the larger quantities of modules that they may be discarding; this group may also have a smaller level of awareness or compliance with RCRA and related regulations. Clearly, a common thread, across all three groups is the need for establishment of incentives, and an educational program to inform customers that such incentives exist.

There are no good estimates available for the cost of recycling. In the shortterm, these ccsts should not be unduly burdensome because of the nonferrous metals industry's apparent interest in nurturing the photovoltaic market, plus the fact that large capacity exits. In the long-term as the costs of environmental externalities become more fully incorporated into the true cost of providing energy, they will clearly add to the cost of photovoltaic produced power, but hopefully only in a small way.

To reduce the potential cost associated with the need to recycle modules and production wastes, the Workshop participants urged the photovoltaic industry to continue to take a proactive stance with regard to industrial ecology and to regulatory issues. This means that the industry should:

- Design modules that can be easily disassembled and also contain materials which can be recycled (for example glass with less $\mathrm{Na}$ ). In this way the image of the industry can be improved and economic advantages will be realized.

- $\quad$ Reduce generated waste throughout the process.

- $\quad$ Reduce quantity of rejected modules through quality control.

- $\quad$ Reduce quantity of broken final products through quality control and shipping package improvements.

- Focus R\&D on process efficiency to reduce material utilization.

- Use less material by improving the physical and electrical properties of the cell and decreasing the cell thickness.

\section{CONCLUSIONS}

There is still much uncertainty regarding the precise health hazards presented by the compounds used in the manufacture of II-V and III-VI photovoltaic devices and the applicability of EPA and OSHA regulations on photovoltaic module manufacturers. 
Nevertheless, it would be prudent to minimize the use of these materials, and to implement programs that will help ensure safe working conditions in manufacturing facilities and a clean environment. In this context, it is not so much a question as to what strategies exist to meet these objectives, but rather: Which should be chosen and what will the costs be for their implementation? Irrespective of the options selected, it is clear that a strong proactive response by industry is needed to ensure the commercial success of these promising new technologies.

\section{REFERENCES}

1. T. Coutts, L.L. Kazmerski, and S. Wagner, Special Issue - Prociedings of the SERI Photovoltaics Safety Conference, January 16-17, 1986, Lakewood, CO, USA, 19(3-4):287-300, (Solar Cells, 198/).

2. W. Luft, Editor, AIP Conference Proceedings 166 - Photovoltaic Safery, (American Institute of Physics, New York, New York, 1988).

3. American Conference of Governmental Industrial Hygienists, Hazard Assessment and Control Technology in Semiconductor Manufacturing. (Lewis Publishers, Chelsea, MI., 1989).

4. V.M. Fthenakis and P.D. Moskowitz, "An Assessment Of Silane Explosion Hazards," 33(1):81-85, . (Solid State Tech, 1990).

5. J.C. Lee and P.D. Moskowitz, "Hazard Characterization And Management Of Arsine And Gallium Arsenide In Large-Scale Production Of Gallium Arsenide Thin-Film Photovoltaic Cells," 18:41-54, (Solar Cells, 1986).

6. P.D. Moskowitz, "Health And Safety Issues In Photovoltaic Cell Manufacturing," In Current Topics in Photovolraics, T.J. Coutts and J. D. Meakin (Editors), 4:34181, (Academic Press, London, 1990).

7. OSHA, "Occupational Exposure to Cadmium: Notice of Limted Reopening of Rulemaking Record," 47348-47349, (Fed. Reg. 29 Parts 1910 and 1926, 1991).

8. G. Oberdorster, "Assessment Of Lung Cancer Risk From Inhaled Environmental Cadmium," 23: 41-51, (Toxicol Environ Chem, 1989).

9. G. Oberdorster and C. Cox, "Carcinogenicity Of Cadmium In Animals: What Is The Significance For Man," 27:181-195, (Toxicol Environ Chem, 1990).

10. F. Pott, U. Zeim, F.J. Reiffer and others, "Carcinogenicity Studies On Fibers, Metal Compounds, And Some Other Dusts In Rats," 32:129-152, (Exp Pathol, 1987). 
11. H. Oldiges, D. Hochrainer, and U. Glasser, "Long-Term Inhalation Study With Wistar Rats And Four Cadmium Compounds," 19:217-222, (Toxicol. Environ. Chem, 1989).

12. S. Takenaka, U. Glaser, H. Oldiges and U. Mohr, "Morphological Effects Of Cdo Aerosols On The Rai Lung, " 27:163-172, (Toxicol Environ Chem, 1990).

13. B.A. Hart, "Cellular And Biochemical Response Of The Rat Lung To Repeated Inhalation Of Cadmium," 2:281-291, (Toxicol Appl Pharmacol, 1986).

14. J.M. Peters, D. Thomas, H. Falk, G. Oberdorster and T.J. Smith, "Contribution of Metals to Respiratory Cancer, " 70:71-83, (Environ Health Perspect., 1986).

15. U. Glaser, F. Hochrainer, F.J. Otto, and H. Oldiges, "Carcinogenicity And Toxicity Of Four Cadmium Compounds Inhaled By Rats," 27:153-162, (Toxicol Environ Chem, 1990).

16. H. Oldiges and U. Glaser, "Low Level Inhalation Experiments With Four Different Cadmium Compounds In Rats," 11:351-357, (Toxicol Environ Chem, 1986).

17. OSHA, "Occupational Exposure To Cadmium; Proposed Rule," 4052-4147, (Fed Reg 29 CFR Part 1910, 1990).

18. M.J. Thun, C.G. Elinder and L. Friberg, "Scientific Basis For An Occupational Standard For Cadmium, ' 20: 629-642, (Am J Ind Med, 1991).

19. OSHA, "Process Safety Management Of Highly Hazardous Chemicals; Explosives And Blasting Agents; Final Rule," 57(36):6356-6417, (Fed. Reg., 1992).

20. P.D. Moskowitz. and K.M. Zweibel, Editors, Recycling of Cadmium and Selenium from Photovoltaic Module Production and Use: A Workshop Report, (in preparation).

\section{DISCLAIMER}

This report was prepared as an account of work sponsored by an agency of the United States Government. Neither the United States Government nor any agency thereof, nor any of their employees, makes any warranty, express or implied, or assumes any legal liability or responsibility for the accuracy, completeness, or usefulness of any information, apparatus, product, or process disclosed, or represents that its use would not infringe privately owned rights. Refer. ence herein to any specific commercial product, process, or service by trade name, trademark, manufacturer, or otherwise does not necessarily constitute or imply its endorsement, recommendation, or favoring by the United States Government or any agency thereof. The views and opinions of authors expressed herein do not neressarily state or reflect those of the United States Government or any agency thereof. 

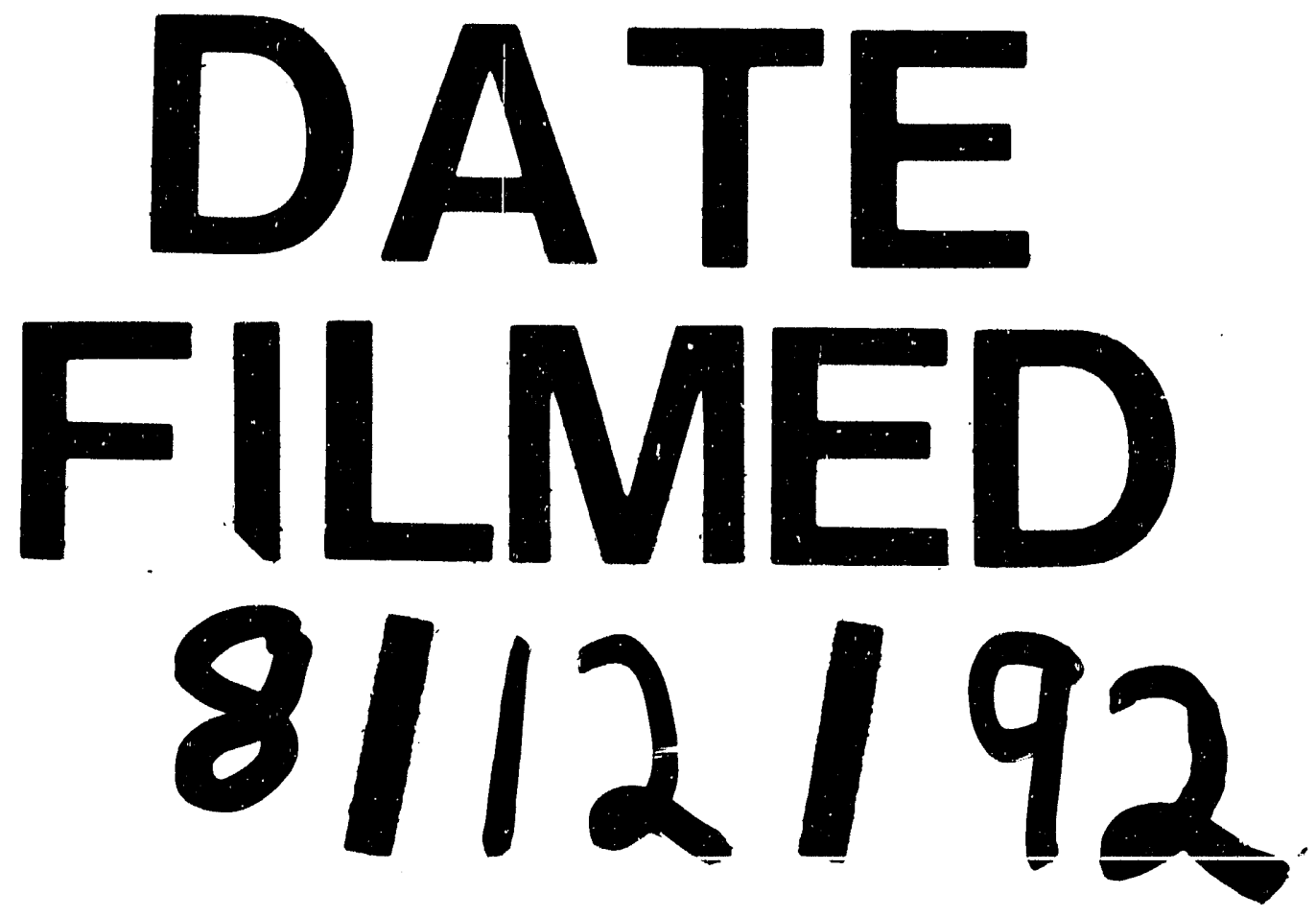

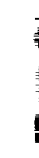


